\title{
MODELING KEY SELECTED MULTISENSORY DIMENSIONS ON PLACE SATISFACTION AND PLACE ATTACHMENT AMONG TOURISTS IN VICTORIA FALLS, ZIMBABWE
}

\author{
Modjadji Matilda MASHAPA* \\ University of Johannesburg, School of Tourism and Hospitality, \\ College of Business and Economics, South Africa, e-mail: mmashapa@uj.ac.za \\ Eugine Tafadzwa MAZIRIRI \\ University of the Witwatersrand, School of Economics and Business Sciences, \\ Faculty of Commerce, Law and Management, Private Bag 3, WITS, 2050, \\ Johannesburg, South Africa, e-mail: euginemaziriri@gmail.com \\ Welcome MADINGA \\ University of Cape Town, School of Management Studies, Department \\ of Marketing, South Africa, e-mail: welcome.mading@uct.ac.za
}

\begin{abstract}
Citation: Mashapa, M.M., Maziriri, E.T., \& Madinga, W. (2019). MODELING KEY SELECTED MULTISENSORY DIMENSIONS ON PLACE SATISFACTION AND PLACE ATTACHMENT AMONG TOURISTS IN VICTORIA FALLS, ZIMBABWE. GeoJournal of Tourism and Geosites, 25(2), 580-594. https://doi.org/10.30892/gtg.25224-382
\end{abstract}

\begin{abstract}
This study investigated the influence of multisensory dimensions on place satisfaction and attachment in the African tourism context. Using a data set consisting of 151 tourists who had visited the Victoria Falls of Zimbabwe, the study examines the relationships involved. All the posited six hypotheses are supported. The results indicate that the relationship between sight, sound and place satisfaction, as well as the relationship between place satisfaction, place dependence, place identity, place affect, and place social bonding were significantly positive. The research paper discusses both the academic and the managerial implications of the results, and future research directions are suggested.
\end{abstract}

Key words: Sight, sound, place satisfaction, place attachment, Zimbabwe

\section{INTRODUCTION}

Due to the local activities, a lovely natural landscape, important individuals, or symbolic meanings, tourists form an attachment to a destination (Yuksel et al., 2010). Gross and Brown (2008) propose that the amount of tourist participation in a location is favourably linked to the degree of place attachment of the visitors concerned. Yuksel et al. (2010) verify that the intention to revisit the site can be efficiently predicted by location

\footnotetext{
* Corresponding author
} 
Modeling Key Selected Multisensory Dimensions on Place Satisfaction and Place Attachment Among Tourists in Victoria Falls, Zimbabwe

attachment. Hidalgo and Hernandez (2001), therefore, indicate that individuals develop a desire to remain close to specific locations. Individuals are also claimed to describe themselves as belonging to certain locations (Stedman, 2002). Thus, in relation to particular settings, they may shape their identity (Shamsuddina \& Ujangb, 2008). The attachments concerned may occur on various scales, such as a neighbourhood, a certain landscape, a village, or a bigger region than the aforementioned (Schilar \& Keskitalo, 2018). As far as tourism actors are concerned, individuals are possibly connected to the built tourist 'location', or make sense of location alongside other geographical scales (Schilar \& Keskitalo, 2018). Connections, or bonds, between people and sites are conceived as site attachments (Line et al., 2018; McDowell, 2018; Woosnam et al., 2018). Previous studies have demonstrated place importance in predicting revisit behaviour or behavioural intent (Lee et al., 2012; Loureiro, 2014) and how place attachment mechanisms play a different role in terms of tourism decision-making (Kil et al., 2012; Lee et al., 2012; Prayag \& Ryan, 2012). This discussion is inconclusive, because the majority of the previous studies include place attachment with only two or three sub-dimensions (Kuo et al., 2018). The amount of research undertaken into place attachment combined with the four sub-dimensions (i.e. place identity, place dependence, place social bonding, and place affect) (Xu et al., 2016) has, so far, been limited.

Against the above-mentioned background, and based on the discussion of the importance of place attachment, it is essential to note that the prior researchers within the African context have, among others, examined place attachment in different settings, focusing on place attachment and on living arrangement determinants in a family house in Ibadan, Nigeria (Akinjokun et al., 2018); on gated nature and its role in establishing place attachment and place of identity in post-apartheid South Africa: on analysis of the private housing property in Grotto Bay (Ramsawmy, 2017); on place attachment in Newtown, Johannesburg (Van Loggerenberg, 2007); and on the background of the allegiance of visitors to Mauritius with regard to the role and impact of the target picture, attachment, private participation, and happiness (Prayag \& Ryan, 2012). Along such lines, there appears to be a lack of research into the key multisensory dimensions influencing place satisfaction and place attachment, leading to the basic motive behind the current inquiry being to fill the existing gap in knowledge pertaining to the above. Furthermore, no, or few, researchers have yet used structural equation modelling (SEM) to assess the causal relationships of sight, sound, place satisfaction, and place attachment dimensions to the utmost understanding of the investigators involved. The research model is also unique in terms of its robustness in relation to the study in question. Moreover, the study gap limits the holistic knowledge of the perceptions, experiences and behaviours of tourists. Furthermore, the impact of place attachment on the intention of visitors to revisit is contentious. Some studies conclude that place attachment directly predicts revisit behavioural intent (Loureiro, 2014; Shi et al., 2016), while others address the indirect impact through other mediating factors, such as location satisfaction, or attitude (Lee et al., 2012).

The absence of a solid theoretical context is ascribed to the inconclusive explanations as yet given for the connection between location attachment and revisit conduct. To tackle the existing gaps, the present research uses the interpersonal attachment theory to enhance the clarification of the theoretical connection between place satisfaction and place attachment, by means of revisiting the issue of destination, using the chosen multisensory dimensions of the visitors concerned. The current article is structured as follows: the theoretical grounding is provided, followed by the conceptual framework. The literature review, together with the hypothesis statements, is presented. The research design and 
methodology, as well as the study demarcation area, is then described, the findings submitted, and the central issue discussed. The final parts of the article address the implications, constraints and instructions of the present research for future studies.

\section{THEORETICAL GROUNDING: THE INTERPERSONAL ATTACHMENT THEORY}

To attain a clear understanding of the context of the present research, the current study is anchored within the framework of the interpersonal attachment theory, which is deemed to provide an appropriate theoretical grounding for the study.

The attachment theory describes the innate human need to form affectionate bonds (Bowlby, 1980). Additionally, the theory propounds that attachment to figures is an inborn behavioural system (Chinomona \& Maziriri, 2017). Amin and Malin (2012) point out that, according to the theory in question, a child shows separation anxiety and distress as soon as a parent or significant other is no longer present. Such behaviour indicates attachment to place, with the consumer showing feelings of regret and sorrow when the desired object is no longer available (Amin \& Malin, 2012). Conversely, Moussa and Touzani (2013, p. 339) argue that many of the attachment theory's premises are transferable to the consumer-brand relationship. According to Ismail and Ali (2013, p. 55), the basic underlying premise of attachment theory is "Separation Distress", which refers to the extent to which consumers show their emotions when they are exposed to real, or imagined, separation from an object of strong attachment. Thomson (2006) suggests that the attachment theory can have input into the conceptualisation of destination marketing, because of the distinctive qualities pertaining to an attachment.

Therefore, based on the authors' explanations, it can be noted that, the consideration of attachment theory could assist the tourism managers at various natural tourism geographical sites to gain a thorough understanding of what motivates tourists to seek satisfaction from, and, ultimately, to become attached to, a place like Victoria Falls.

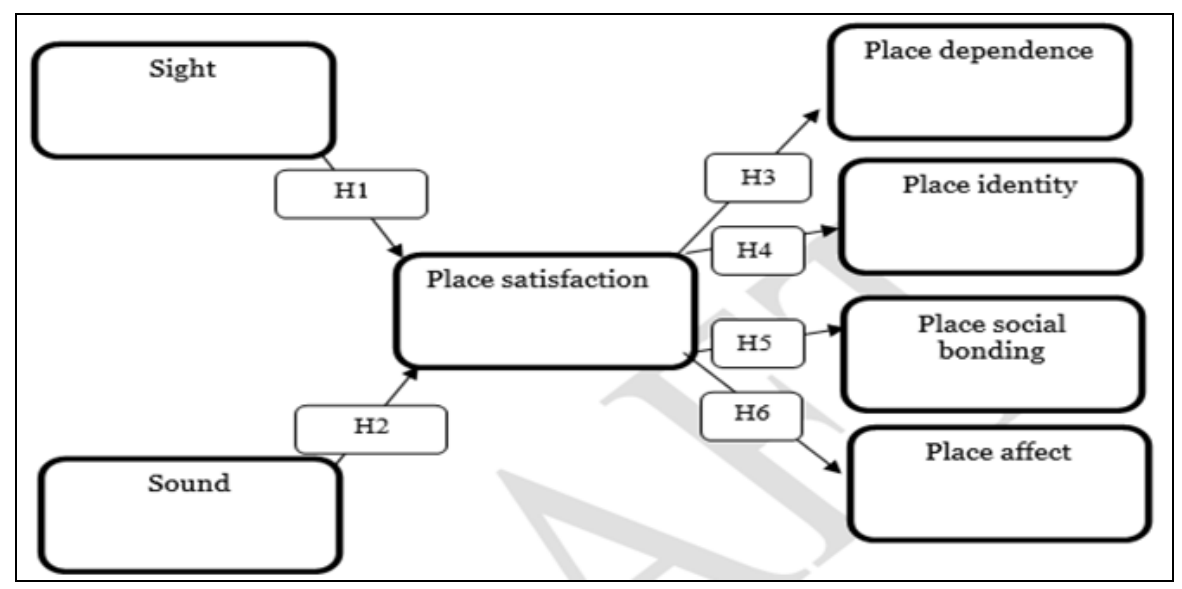

Figure 1. Conceptual framework

\section{Conceptual Model and Hypothesis Development}

The connection between variables investigated in the research is described in terms of a conceptual model (Maziriri et al., 2018). Furthermore, Maziriri et al., (2018) note that 
Modeling Key Selected Multisensory Dimensions on Place Satisfaction and Place Attachment Among Tourists in Victoria Falls, Zimbabwe

a conceptual model schematic diagram enables the viewer to visualise the theoretical interactions between the factors in the model, and, thus, to ascertain quickly how a leadership issue can be solved. The conceptual model in the present research indicates that sight and sound are the predictor variables.

In addition, the model also suggests that place satisfaction is the mediator variable. Moreover, the dependent, or outcome, variables for the current study model are place dependence, place identity, place social bonding, and place affect. Based on a synthesis of the converging literature related to the research variables concerned, a conceptual model was, accordingly, proposed to guide the empirical study, as is shown in Figure 1.

\section{LITERATURE REVIEW}

\section{Sight}

Sight has commonly been recognised as a sensory dimension impacting on the subjective perception of visitors, as well as on consequent conduct, and choice of destination (Mao \& Lyu, 2017; Miller et al., 2017; Hartwell et al., 2018; Wu et al., 2018). Tourism management theorists have defined sight (destination image) as consisting of a set of impressions, ideas, expectations, and emotional thoughts that tourists hold of a place (Foroudi et al., 2018; Lin et al., 2011), representing the associations and pieces of information related to a destination (Rahmani et al., 2019). Destinations with more favourable pictures are thought to be more likely to be included in the decision-making process. Furthermore, the holding of a destination picture has a beneficial impact on perceived quality and satisfaction (Papadimitriou et al., 2018). Increased tourist satisfaction results in a comparatively favourable picture. In the above-mentioned context, the Victoria Falls is seen as one of the world's most dramatic natural attractions (Cosgrove, 2018). Affectionately known as 'Mosi-oa-Tunya', meaning the smoke that thunders, the Falls consist of a towering spray column that drops away in a beautiful cascade, when the Zambezi River is high. The Victoria Falls are known as the favourite tourist attraction in Zimbabwe, and throughout most of Africa, due to the amazing views, landscapes and broad variety of operations that are associated therewith (Matura \& Mapira, 2018).

Hypothesis 1: Sight positively influences tourists'sense of place satisfaction.

\section{Sound}

Sound, which is a basic component of immersing visitors in 'sensing' the destination of tourism, plays a key role in shaping the experiences and the happiness of tourists in terms of destinations (Henrique de Souza et al., 2018). As noise is an important component of tourist attractions and tourism products, the sound of a destination is described as the nature and magnitude of the auditory component that is perceived by visitors at a destination (Neuburger et al., 2018). The sound environment generated at the location, thus, adds considerably to the general tourism experience of the tourists visiting there. In addition, the presence of sound emphasises the interrelationships between listeners, sounds and the surrounding environment, and takes into consideration the destination's social, cultural and aesthetic significance (Al-Saad et al., 2014). The Victoria Falls is one such place, with it being characterised by the thunder of falling water, the stunning gorge, and the quiet lagoons upstream, where hippos and crocodiles reside (Davidson, 2012). Against such a background, therefore, efficient sound management is as essential as is maintaining the visual picture of a destination. The above is so because sound can improve the picture of a destination, and it may also define a feeling of location.

Hypothesis 2: Sound positively influences tourists'sense of place satisfaction. 


\section{Place satisfaction}

Ramkissoon et al., (2012) describe place satisfaction as consisting of the perceived quality of an environment in terms of meeting the requirements of tourists relating to the physical characteristics and facilities concerned. Those individuals who are relatively well attached to a natural environment are more likely to be satisfied by the place than are others who are less well attached to it (Prayag \& Ryan, 2012). Place satisfaction is seen as a key to the achievement of many tourist destinations (Chen \& Dwyer, 2018). Emotions are seen to play a significant part in the creation of satisfaction by tourism attractions (Yan et al., 2018). Place satisfaction consists of a multidimensional summary judgment of the perceived performance of an environment, in regard to whether it meets the requirements of an individual in terms of the physical features of a place, as well as its facilities and social dimensions, according to Han et al. (2019). Although some studies, including that of Eusébio et al., (2018), have shown the connections between the dimensions of place attachment and place satisfaction, further study is justified in terms of investigating the connection between the two constructs. Evidence indicates that place attachment, which is conceptualised as place dependency, place identity (Eusébio et al., 2018; Prayag et al., 2018), and place influence (Prayag et al., 2018), can play a substantive role in predicting the levels of tourist satisfaction experienced. However, the literature still has to establish the connection between place social bonding and place satisfaction (Ramkissoon et al., 2012). Thus, place satisfaction and place attachment in today's competitive market are viewed as being key to the achievement of nature-based attractions (Schilar \& Keskitalo, 2018).

\section{Place attachment}

Place attachment relates to the emotional and psychological bonds that have been established between a person and a specific place (Fu et al., 2019), as well as to the extent to which people value, and identify with, specific environmental environments (Ballantyne et al., 2018). Han et al., (2019) state that a place attachment can be understood in relation to individuals within a natural setting, in terms of which identification, gratification, and concern for distinctive environments is evoked, thus affecting the related human affections, perceptions, and behaviours (Eller \& Frey, 2019). Place attachment is, therefore, considered to be a unique marketing force for tourism, which has a significant effect on the creation of the attitude allegiance of the tourist, and which revisits the conduct adopted towards the destination (Lai et al., 2019). Studies have shown that place attachment also plays a significant part in tourist experiences covered in tourism research (Io \& Wan, 2018), as place attachment intensity enhances loyalty and revisit behaviour (George \& George, 2012). Positive tourism experiences can determine the satisfaction of visitors and their emotional attachment to a destination (Io \& Wan, 2018). The above study indicates a need to further examine the function of satisfaction in predicting place attachment, in terms of its four sub-dimensions (reliance, identity, impact, and social bonding).

\section{Place Dependence}

In a tourism and leisure context, place dependence is described as visitors' functional attachment to a specific place, and their awareness of the uniqueness of a setting, which contributes to meeting their visitation goals (Silva et al., 2018). Such functional attachment reflects the importance of a resource in providing required services for desired recreational activities (Abou-Shouk et al., 2018), with it being embodied in the physical characteristics of a setting (the Victoria Falls) (Wiltshire et al., 2019).

Hypothesis 3: Place satisfaction positively influences tourists sense of place dependence. 
Modeling Key Selected Multisensory Dimensions on Place Satisfaction and Place Attachment Among Tourists in Victoria Falls, Zimbabwe

\section{Place Identity}

Shamir and Eilam-Shamir (2018) state that place identity refers to the connection between a place and one's personal identity, with it containing both cognitive and affective elements. Natural settings, like the Victoria Falls, offer individuals the opportunity to develop a sense of identity with a place (Chen et al., 2018), due to the latter's uniqueness, or distinctiveness, from other places (Truong et al., 2018). Several researchers have operationalised place attachment, using just the two sub-constructs of place dependence and place identity (Combrinck, 2018; Truong et al., 2018).

Hypothesis 4: Place satisfaction positively influences tourists sense of place identity. Place Affect

Some researchers conceptualise place attachment as including place affect (Kals et al., 1999; Ramkissoon et al., 2012). While, in the environmental psychology and tourism literature, destinations are widely acknowledged as being grounded in environmental and social experiences (Price et al., 2018; Schild, 2018), they also note an affective link that individuals develop by building their sentiments about the place (Slaby et al. 2019). Within the context of the current study, affective connection with Victoria Falls generates a sense of psychological well-being for tourists. Therefore, it is evident that natural settings tend to further increase positive emotions in individuals about the setting (Fonagy, 2018a; Wyles et al., 2019). Individuals with relatively extensive experience with natural environments might express stronger emotional attachment with those environments than do those with less experience of such environments (Wood \& Kenyon, 2018).

Hypothesis 5: Place satisfaction positively influences tourists sense of place affect.

\section{Place Social Bonding}

Another sub-dimension of place attachment is place social bonding. A place can be valued by an individual, due to it facilitating the development of interpersonal relationships (Moulay et al., 2018), and due to it fostering a sense of 'group belonging' (Truong et al., 2018). In terms of such spatial contexts, individuals tend to develop communal bonds with others through people-place interaction (Wellman, 2018; Jovchelovitch, 2019). Fonagy (2018b) and Ramkissoon et al., (2018) argue that natural settings set the context for social experiences which, if they are maintained in such settings, are likely to lead to relatively high levels of attachment. Place social bonding was found to be a strong predictor of place attachment by Tumanan and Lansangan (2012). Social bonds, in fact, can be the primary source of meaning in some contexts (Fonagy, 2018b). Taken together, the multivalent nature of place illustrates the cultivation of place attachment through dependence, identity, affect, and the socially shared experiences associated with the place. The above review suggests that place attachment is a multidimensional construct consisting of place dependence, place identity, place social bonding, and place affect. Each sub-construct is conceptually different from the others, with it reflecting the various underlying dimensions of place attachment (Fonagy, 2018a; Ramkissoon et al., 2018; Wyles et al., 2019). bonding.

Hypothesis 6: Place satisfaction positively influences tourists sense of place social

\section{MATERIALS AND METHODS}

The current study submits to the positivist paradigm, since it intends to test several a priori hypotheses to determine the relationships concerned existing between the independent and dependent variables. The authors selected to adopt a quantitative research approach, since the application of such an approach increases the degree of 
accuracy attained through statistical analysis. The adoption of the design justified requesting the required data related to sight, sound, place satisfaction, place dependence, place identity, place affect, and place social bonding.

The Victoria Falls is one of the most famous geographical characteristics of the African continent as a whole. The international fame of the Falls relies heavily on concepts of natural form and beauty rooted in European romantic and natural history traditions, which have earned it a prominent place in the worldwide lexicon of natural wonders (McGregor, 2003). In addition, the town of Victoria Falls is Zimbabwe's most prominent tourist destination, with it being chosen as the country's main attraction, and the main venue for Africa's basketball (Mudimba \& Tichaawa, 2017). The destination offers such prominent tourist-related activities as bungee jumping, gorge swinging, abseiling, elephant-back paths, and cheetah walking, which distinguishes it from other locations on the continent (Mudimba \& Tichaawa, 2017). The current study centres on the Victoria Falls, and on visitors to the destination.

\section{Research Instrument and Questionnaire Design}

Table 1 depicts the demographic data of the participants, including their gender, age, marital status, and frequency of visits to the Victoria Falls. The respondents were found to be mainly women (57.6\%), with the average age of the respondents being under 30 years old (54.3\%). Of the respondents, $57 \%$ were single. Their degree of agreement with the statements made was indicated on a scale of 1 (strongly disagree) to 5 (strongly agree).

\section{Participants and Sampling}

Table 1 displays the depiction of the participants. The respondents were requested to report their demographic data, including gender, age, marital status and frequency of visit to the Victoria Falls. The respondents were mainly females (57.6\%). The average age of the respondents was under 30 years (54.3\%). Fourthy-three per cent of the respondents were married.

Table 1. Sample demographic characteristics

\begin{tabular}{|c|c|c|}
\hline Characteristics & Frequency & \% \\
\hline Gender & & \\
\hline Male & 64 & 42.4 \\
\hline Female & 87 & 57.6 \\
\hline Total & 151 & 100.0 \\
\hline Age & & \\
\hline$\leq 30$ & 82 & 54.3 \\
\hline $31-60$ & 51 & 33.8 \\
\hline$\geq 60$ & 18 & 11.9 \\
\hline Total & 151 & 100.0 \\
\hline Marital status & & \\
\hline Married & 65 & 43.0 \\
\hline Single & 86 & 57.0 \\
\hline Total & 151 & 100.0 \\
\hline
\end{tabular}

\section{RESULTS AND DISCUSSIONS}

The research model developed in the present investigation was tested using partial least squares (PLS), which is a variance-based structural equation modelling approach (Subramaniama et al., 2017). Additionally, Monecke and Leisch (2012, p. 3) elucidate that "SmartPLS is stand-alone software specialized for PLS path models and it is built on a Java Eclipse platform making its operating system independent". Partial least squares can 
facilitate the assessment of both the measurement and structural models (Subramaniama et al., 2017). The current study utilised PLS for two main reasons: firstly, the aim of the study was oriented towards the prediction of the dependent variable (Chin, 2010), and, secondly, the latent variable scores were used in the subsequent analysis for predictive relevance (Hair et al., 2011). Furthermore, Hair et al., (2011) stress that such arguments have led to the widespread acceptance of PLS in research. Specifically, the present study used the smart PLS approach introduced by Ringle et al., (2005).

Table 2. Accuracy statistics table

\begin{tabular}{|c|c|c|c|c|c|c|c|c|}
\hline \multirow{2}{*}{$\begin{array}{l}\text { Research } \\
\text { constructs }\end{array}$} & \multirow{2}{*}{$\begin{array}{l}\text { PLS } \\
\text { code } \\
\text { item }\end{array}$} & \multicolumn{2}{|c|}{$\begin{array}{c}\text { Descriptive } \\
\text { statistics* }\end{array}$} & \multicolumn{2}{|c|}{ Cronbach's test } & \multirow{2}{*}{ CR } & \multirow{2}{*}{ AVE } & \multirow{2}{*}{$\begin{array}{l}\text { Measurement } \\
\text { item loadings }\end{array}$} \\
\hline & & Mean & SD & $\begin{array}{l}\text { Item- } \\
\text { total }\end{array}$ & $\begin{array}{c}\text { Cronbach'salpha } \\
\text { value }\end{array}$ & & & \\
\hline \multirow{3}{*}{ Sight } & ST1 & \multirow{3}{*}{3.03} & \multirow{3}{*}{1.300} & 0.716 & \multirow{3}{*}{0.713} & \multirow{3}{*}{0.843} & \multirow{3}{*}{0.646} & 0.898 \\
\hline & ST2 & & & 0.784 & & & & 0.856 \\
\hline & ST3 & & & 0.750 & & & & 0.632 \\
\hline \multirow{6}{*}{ Sound } & SD1 & \multirow{6}{*}{3.79} & \multirow{6}{*}{1.655} & 0.741 & \multirow{6}{*}{0.851} & \multirow{6}{*}{0.891} & \multirow{6}{*}{0.581} & 0.834 \\
\hline & SD2 & & & 0.872 & & & & 0.904 \\
\hline & SD3 & & & 0.781 & & & & 0.765 \\
\hline & SD5 & & & 0.775 & & & & 0.618 \\
\hline & SD6 & & & 0.767 & & & & 0.802 \\
\hline & SD7 & & & 0.719 & & & & 0.603 \\
\hline \multirow{3}{*}{$\begin{array}{c}\text { Place } \\
\text { satisfaction }\end{array}$} & PS1 & \multirow{3}{*}{3.10} & \multirow{3}{*}{1.133} & 0.718 & \multirow{3}{*}{0.719} & \multirow{3}{*}{0.843} & \multirow{3}{*}{0.642} & 0.843 \\
\hline & PS2 & & & 0.754 & & & & 0.819 \\
\hline & PS3 & & & 0.726 & & & & 0.739 \\
\hline \multirow{3}{*}{$\begin{array}{c}\text { Place } \\
\text { dependence }\end{array}$} & PD1 & \multirow{3}{*}{3.23} & \multirow{3}{*}{1.239} & 0.736 & \multirow{3}{*}{0.794} & \multirow[t]{3}{*}{0.876} & \multirow[t]{3}{*}{0.702} & 0.868 \\
\hline & PD2 & & & 0.739 & & & & 0.852 \\
\hline & PD3 & & & 0.729 & & & & 0.790 \\
\hline \multirow{3}{*}{$\begin{array}{c}\text { Place } \\
\text { identity }\end{array}$} & PI1 & & & 0.815 & & & & 0.884 \\
\hline & PI2 & $3 \cdot 37$ & 1.394 & 0.843 & 0.850 & 0.909 & 0.769 & 0.908 \\
\hline & PI3 & & & 0.853 & & & & 0.837 \\
\hline & PA1 & & & 0.621 & & & & 0.500 \\
\hline Place affect & PA2 & 3.63 & 1.470 & 0.741 & 0.615 & 0.757 & 0.519 & 0.801 \\
\hline & $\mathrm{PA} 3$ & & & 0.798 & & & & 0.816 \\
\hline Place social & PSB1 & & & 0.774 & & & & 0.992 \\
\hline bonding & PSB3 & 3.90 & 1.588 & 0.771 & 0.670 & 0.749 & 0.622 & 0.509 \\
\hline
\end{tabular}

Note: ST = Sight; SD = Sound; PS = Place satisfaction; PD = Place dependence; PI = Place identity; PA = Place affect; PSB = Place social bonding.

The researchers checked the measurements' reliability and validity. The reliability of the study was checked using mainly the composite reliability (CR) and Cronbach's alpha values. To ensure the convergent validity of the study, the researcher checked whether the items loaded on their respective (a priori) constructs with loadings greater than 0.5 , while the discriminant validity was checked by means of the use of the average variance extracted (AVE) value, and by means of ensuring that no significant interresearch variable cross-loadings were present (Chin, 1998). Moreover, the statistical measures of accuracy tests, as shown in Table 2, specify the different measures that were used to assess the reliability and validity of the constructs for the study.

Confirmatory factor analysis (CFA) was employed, and the SEM was estimated with the PLS data. Table 3 and Figure 2 depict the CFA findings that were made, 
whereas Table 4 and Figure 2 summarise the SEM findings. The CFA was used to evaluate the measurement model, representing the outer model in PLS. Maria and Yusniza (2016:1) mention that the purpose of the measurement model is to "evaluate the reliability and validity of variables". Table 2 shows that the item-total correlation value lies between 0.621 and 0.872 , which is above the cut-off point of 0.5 , as recommended by Anderson and Gerbing (1988, p. 411). The higher inter-item correlations reveal convergence among the measured items. Nunnally and Bernstein (1994, p. 1) explain that "alpha values should exceed 0.6". All variables in the current study represented good reliability, with the Cronbach's alpha being between 0.615 and 0.851 .

The study also used CR values in testing the reliability of the five research constructs, with the values ranging between 0.749 and 0.909 . The values obtained from the CR exceeded the acceptable reliability score of 0.7 , thus validating the internal consistency of the five research construct measures, according to Nunnally and Bernstein (1994). The result shows that the AVE of the study ranged between 0.519 and 0.762. The AVE values exceeded the recommended 0.40 , indicating a satisfactory measure (Anderson \& Gerbing, 1988, p. 411). As shown in Table 2, "loadings of all items should be more than the suggested value of 0.5 " (Hair et al., 2009 p. 23). Factor loadings in the study met the specification of the recommended value of 0.5 , ranging from 0.500 to 0.992. Items PSB2 and SD4 were deleted, due to the low factor loadings that were below 0.5. The remaining items fulfilled the requirement of reliability and convergent validity. According to Hair et al., (2013, p. 13), discriminant validity refers "to items measuring different concepts". Table 3 indicates the results of discriminant validity obtained.

Table 3. Results of discriminant validity analysis

\begin{tabular}{|l|c|c|c|c|c|c|c|}
\hline Variables & ST & SD & PS & PD & PI & PA & PSB \\
\hline ST & 1.000 & - & - & - & - & - & - \\
\hline SD & 0.494 & 1.000 & - & - & - & - & - \\
\hline PS & 0.343 & 0.540 & 1.000 & - & - & - & - \\
\hline PD & 0.491 & 0.565 & 0.347 & 1.000 & - & - & - \\
\hline PI & 0.294 & 0.447 & 0.566 & 0.501 & 1.000 & - & - \\
\hline PA & 0.527 & 0.402 & 0.537 & 0.488 & 0.412 & 1.000 & \\
\hline PSB & 0.342 & 0.458 & 0.500 & 0.478 & 0.312 & 0.234 & 1.000 \\
\hline
\end{tabular}

Note: $\mathrm{ST}=$ Sight; $\mathrm{SD}$ = Sound; PS = Place satisfaction; $\mathrm{PD}$ = Place dependence; PI = Place identity; PA = Place affect; $\mathrm{PSB}=$ Place social bonding.

\section{Inter-construct Correlation Matrix}

Nunnally and Bernstein (1994) have shown that one of the methods used to check for the discriminant validity of research constructs is the evaluation of whether the correlations among latent constructs are less than 0.60. A correlation value of less than 0.60 is recommended in the empirical literature to confirm the existence of discriminant validity (Nunnally \& Bernstein, 1994). As can be seen, all the correlations in the present study are below the standard level of 0.60 , which indicates the existence of discriminant validity. As shown in Table 3, the inter-construct correlation values range from 0.234 to 0.566 below the rule of thumb of 0.8 (Fraering \& Minor, 2006), indicating the attainment of discriminant validity. Therefore, Table 3 above shows that the results serve still further to validate the existence of discriminant validity.

\section{Assessment of the Goodness of Fit (GoF)}

Smart PLS, unlike the AMOS and LISREL software, does not offer the GoF measures for the full path model. Rather, the software simply gives the $\mathrm{R}^{2}$ values for the dependent variables (place satisfaction, place dependence, place identity, place affect, and 
place social bonding). Nevertheless, the GoF in the current article was determined by utilising a universal GoF method, which, according to Tenenhaus, Amato and Vinzi (2004), accounts for both the quality of measurement and the structural model. The following formula was used to calculate the global goodness of fit:

$$
\begin{aligned}
& \text { Goodness of Fit } \left.={ }^{2} \sqrt{(\text { average of all AVEs values }}{ }^{*} \text { average of all } \mathrm{R}^{2}\right) \\
& =2 \sqrt{0.640^{*}} 0.212 \\
& =0.37
\end{aligned}
$$

Where AVE represents the average of all AVE values for the research variables; while $\mathrm{R}^{2}$ represents the average of all $\mathrm{R}^{2}$ values in the full path model.

The calculated global GoF is 0.37, which exceeds the threshold of GoF > 0.36 suggested by Wetzels et al. (2009). Therefore, the present study concludes that the research model has a good overall fit.

\section{Path Model Results and Factor Loadings}

The PLS estimation results for the structural model, as well as the item loadings for the research constructs, are shown in Figure 2.

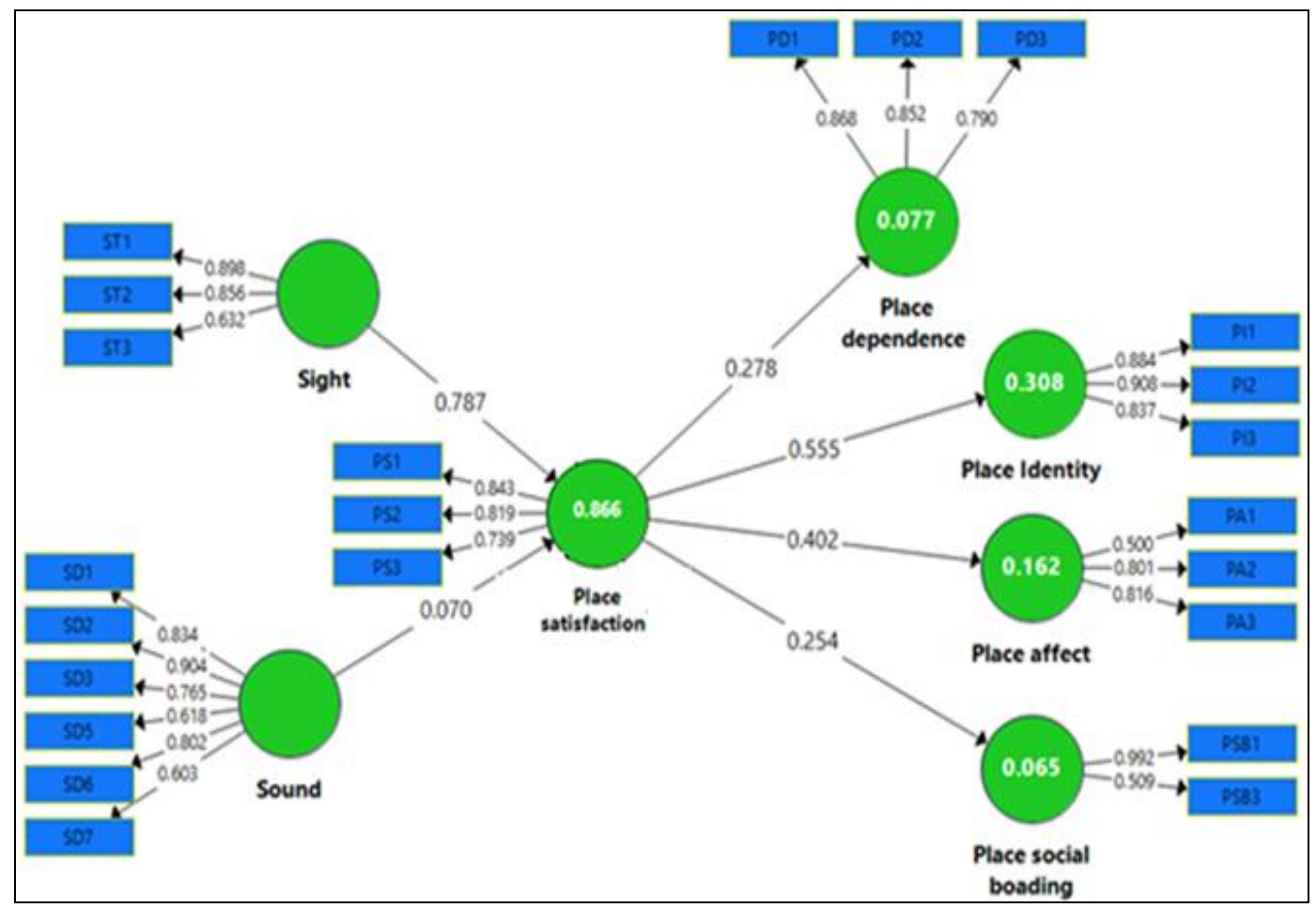

Figure 2. Path modelling and factor loading results

\section{Outcomes of Hypothesis Testing}

In the current study, the testing of the hypothesis was determined by the path coefficient values, as well as the $t$-values for the structural model obtained from the bootstrapping algorithm. According to Beneke and Blampied (2012), the t-values indicate whether or not a significant relationship exists between variables within a model, and the path coefficients demonstrate the strength of the relationships in the model. Two tailed t-tests were conducted at the $5 \%$ significance level. 
In the current study, the related hypothesis was supported. Figure 2 and Table 4 show that sight exerted a positive impact $(\beta=0.787)$, and that it was statistically significant $(t=11.971)$ in predicting place satisfaction. The result suggests that sight positively influences place satisfaction in a significant way. With regards to hypothesis two, Figure 2 and Table 4 show that sound exerted a positive impact $(\beta=0.070)$, and that it was statistically insignificant $(t=1.614)$ in predicting place satisfaction. The result implies that sound directly influences place satisfaction both positively and significantly. In the present study, the related hypothesis was supported.

Figure 2 and Table 4 show that place satisfaction exerted a positive impact on ( $\beta$ $=0.278)$, and was statistically significant $(\mathrm{t}=2.254)$ in, predicting place dependence. The result suggests that place satisfaction positively influences place dependence in a significant way. The fourth hypothesis, which proposed that place satisfaction has a positive impact on place identity, was reinforced in the study.

Table 4. Results of structural equation model analysis

\begin{tabular}{|c|c|c|c|c|}
\hline Path & Hypothesis & $\begin{array}{c}\text { Path } \\
\text { coefficients ( } \beta)\end{array}$ & T-statistics & Decision \\
\hline $\mathrm{ST} \rightarrow$ PS & $\mathrm{H} 1(+)$ & 0.787 & 11.971 & Positive and significant \\
\hline $\mathrm{SD} \rightarrow$ PS & $\mathrm{H} 2(+)$ & 0.070 & 1.614 & Positive and insignificant \\
\hline $\mathrm{PS} \rightarrow$ PD & $\mathrm{H} 3(+)$ & 0.278 & 2.254 & Positive and significant \\
\hline $\mathrm{PS} \rightarrow$ PI & $\mathrm{H} 4(+)$ & 0.555 & 8.943 & Positive and significant \\
\hline $\mathrm{PS} \rightarrow$ PA & $\mathrm{H} 5(+)$ & 0.402 & 5.127 & Positive and significant \\
\hline $\mathrm{PS} \rightarrow$ PSB & $\mathrm{H} 6(+)$ & 0.254 & 2.138 & Positive and significant \\
\hline
\end{tabular}

Note: $\mathrm{ST}=$ Sight $; \mathrm{SD}=$ Sound; $\mathrm{PS}$ = Place satisfaction; $\mathrm{PD}=$ Place dependence; $\mathrm{PI}$ = Place identity; PA = Place affect; PSB = Place social bonding.

Figure 2 and Table 4 indicate that place satisfaction and place identity are supported. Place satisfaction exerted a positive influence $(\beta=0.555)$ on place identity, with it being statistically substantial $(t=8.943)$. The result signifies that place satisfaction is related both positively and meaningfully to place identity. In addition, the fifth hypothesis proposed that place satisfaction has a positive impact on place affect. The related hypothesis was reinforced in the present study. Figure 2 and Table 4 indicate that place satisfaction and place affect were supported. Place satisfaction exerted a positive impact $(\beta=0.402)$ on place affect $(t=5.127)$. The result signifies that place satisfaction is positively related to place affect. Figure 2 and Table 4 show that the related hypothesis is supported significantly. The t-statistic is 2.138 . The strength of the relationship is indicated by the path coefficient $(\beta=0.254)$. The finding suggests that place satisfaction has a positive impact on place social bonding.

\section{Academic and Practical Implications of the Study}

The present study offers implications for academicians. For example, an investigation of the research findings indicates that sight $\rightarrow$ place satisfaction has the strongest mutual influence, as indicated by a path coefficient of $(\beta=0.787)$. Therefore, for academicians in the field of geosites and tourism, the finding enhances their understanding of the relationship between sight and place satisfaction, as it is a useful contribution to the existing literature on the two variables.

On the practitioners' side, the current study therefore submits that tourism managers can benefit from the implications of the findings made. For example, given the robust relationship between place satisfaction and place social bonding $(\beta=0.254)$, tourism managers should find ways of keeping their tourists satisfied in their environment, which would ultimately result to place social bonging among tourists. 
Modeling Key Selected Multisensory Dimensions on Place Satisfaction and Place Attachment Among Tourists in Victoria Falls, Zimbabwe

\section{CONCLUSION}

The current research was undertaken with the aim of investigating the impact of selected multisensory dimensions, like sight and sound, on place satisfaction and place attachment. In particular, six hypotheses were postulated.

To test the proposed hypotheses, the required data were collected from individuals in the town of Victoria Falls in Zimbabwe. The study validates the thesis that such factors as sight and sound are instrumental in stimulating place satisfaction and place attachment among Zimbabwean tourists at Victoria Falls. The managerial implications of the findings were discussed, and the limitations of the study, as well as the future research directions, were indicated. Above all, the study should add new knowledge to the existing body of tourism management literature in the African setting, which is a research context that has been under-researched in the past. Although the present study offers valuable insights into the antecedents of place attachment, it is limited, thus offering avenues for future research. The results of the study were ba sed on a relatively small sample of 151 respondents situated in Victoria Falls, so that the findings may not be generalised to most other geosites of Zimbabwe. Therefore, future studies should consider investigating the other tourism attractions of Zimbabwe.

Doing so should offer additional insights into, and accurate research findings in relation to, the understanding of the antecedents of place satisfaction and place attachment. Furthermore, the researchers concerned adopted only a quantitative research approach. Future research might consider using a mixed-method approach, including both a qualitative and quantitative research design, as a quantitative design technique could prove to be more reliable and objective than the technique employed in the present study, due to the use of statistics to generalise the findings made.

\section{Acknowledgments}

The authors would like to acknowledge the contribution of the anonymous reviewers for their invaluable comments and feedback.

\section{REFERENCES}

Abou-Shouk, M.A., Zoair, N., El-Barbary, M.N. \& Hewedi, M.M. (2018). Sense of place relationship with tourist satisfaction and intentional revisit: Evidence from Egypt. International Journal of Tourism Research, 20(2), 172-181.

Akinjokun, A.A., Jusan, M.B.M. \& Shahminan, R.N.B.R. (2018). Place attachment and determinants of living arrangement in the family house in Ibadan, Nigeria. African Population Studies, 32(3), 1-15.

Al-Saad, S., Dhabi, A. \& Emirate, V.A. (2014). The conflicts between sustainable tourism and urban development in the Jerash Archaeological Site (Gerasa), Jordan. Doctoral Dissertation, Catholic University of Eichstätt-Ingolstadt, Eichstätt.

Amin, B. \& Malin, D. (2012). Love of brand: A story of an on-going romance. Bachelor's Thesis, International Business and Economics Program, Kristianstad University, Kristianstad.

Anderson, J.C. \& Gerbing, D.W. (1988). Structural equation modeling in practice: A review and recommended two-step approach. Psychology Bulletin, 1(3), 411-423.

Ballantyne, R., Hughes, K., Lee, J., Packer, J. \& Sneddon, J. (2018). Visitors' values and environmental learning outcomes at wildlife attractions: Implications for interpretive practice. Tourism Management, 64, 190-201.

Beneke, J. \& Blampied, S., 2012. Driving consumer perceptions through Facebook: An investigation into empowering brands in the 21st century. JMM van den Berg (ed.), pp.47-61.

Bowlby, J. (1980). Attachment and loss: Vol. 3. Loss, sadness and depression. Basic Books, New York.

Brim, R.L., Noon, K.R., Collins, G.T., Stein, A., Nichols, J., Narasimhan, D., Ko, M.C., Woods, J.H. \& Sunahara, R.K. (2012). The fate of bacterial cocaine esterase (CocE): an in vivo study of CocE-mediated cocaine hydrolysis, CocE pharmacokinetics, and CocE elimination. Journal of Pharmacology and Experimental Therapeutics, 34O(1), pp.83-95.

Chen, N. \& Dwyer, L. (2018). Residents' place satisfaction and place attachment on destination brand-building behaviors: Conceptual and empirical differentiation. Journal of Travel Research, 57(8), 1026-1041. 
Chen, X., Orum, A.M. \& Paulsen, K.E. (2018). Introduction to cities: How place and space shape human experience. Wiley, Hoboken, NJ.

Chin, W.W. (2010), How to write up and report PLS analyses, in V. Esposito Vinzi, W.W. Chin, J. Henseler \& H. Wang (Eds), Handbook of partial least squares: Concepts, methods and applications, 655-690, Springer-Verlag, Berlin.

Chin, W.W. 1998. The partial least squares approach to structural equation modeling. Modern methods for business research, 295(2), pp.295-336.

Chinomona, E. \& Maziriri, E.T. (2017). The influence of brand trust, brand familiarity and brand experience on brand attachment: A case of consumers in the Gauteng Province of South Africa. Journal of Economics and Behavioural Studies, 9(1), 69-81.

Combrinck, C. (2018). The use of Rasch Measurement Theory to address measurement and analysis challenges in social science research. Doctoral Dissertation, University of Pretoria, Pretoria.

Cosgrove, D. (2018). The myth and the stones of Venice: an historical geography of a symbolic landscape. In Culture and Society (pp. 19-47). Routledge.

Davidson, J. (2012). Looking for Mrs. Livingstone. Hymns Ancient and Modern Ltd, Norwich.

Eller, E. \& Frey, D. (2019). Psychological perspectives on perceived safety: Social factors of feeling safe. In M. Raue, B. Streicher \& E. Lerner (Eds), Perceived Safety, 43-6o, Springer, Cham.

Eusébio, C., Vieira, A.L. \& Lima, S. (2018). Place attachment, host-tourist interactions, and residents' attitudes towards tourism development: The case of Boa Vista Island in Cape Verde. Journal of Sustainable Tourism, 26(6), 890-909.

Fonagy, P. (2018a). Affect regulation, mentalization and the development of the self. Routledge, London.

Fonagy, P. (2018b). Attachment theory and psychoanalysis. Routledge, London.

Foroudi, P., Akarsu, T.N., Ageeva, E., Foroudi, M.M., Dennis, C. \& Melewar, T.C. 2018. PROMISING THE DREAM: Changing destination image of London through the effect of website place. Journal of Business Research, 83, pp.97-110.

Fraering, M., \& Minor, M.S. (2006). Sense of community: An exploratory study of US consumers of financial services. International Journal of Bank Marketing, 24(5), pp.284-306.

Fu, X., Yi, X., Okumus, F. \& Jin, W. (2019). Linking the internal mechanism of exhibition attachment to exhibition satisfaction: A comparison of first-time and repeat attendees. Tourism Management, 72, 92-104.

George, R., 2011. Marketing tourism in South Africa. Oxford University Press Southern Africa.

Gross, M.J. \& Brown, G. (2008). An empirical structural model of tourists and places: Progressing involvement and place attachment into tourism. Tourism Management, 29(6), 1141-1151.

Hair, J.F., Black, W.C., Babin, B.J., Anderson, R.E. \& Tatham, R.L. (2009). Análise multivariada de dados. Bookman Editora.

Hair, J.F., Ringle, C.M. \& Sarstedt, M. (2011). PLS-SEM: Indeed, a silver bullet. Journal of Marketing Theory and Practice, 19(2), 137-149. https://doi.org/10.2753/MTP1069-6679190202

Hair, J.F., Ringle, C.M. \& Sarstedt, M. (2013). Editorial-partial least squares structural equation modeling: Rigorous applications, better results and higher acceptance. Long Range Planning, 46(1-2), 1-12.

Han, J.H., Kim, J.S., Lee, C.K. \& Kim, N. (2019). Role of place attachment dimensions in tourists' decisionmaking process in Cittáslow. Journal of Destination Marketing \& Management, 11, 108-119.

Hartwell, H., Fyall, A., Willis, C., Page, S., Ladkin, A. \& Hemingway, A. (2018). Progress in tourism and destination wellbeing research. Current Issues in Tourism, 21(16), 1830-1892.

Henrique de Souza, L., Kastenholz, E. \& Barbosa, M.D.L.D.A. (2018). Relevant dimensions of tourist experiences in unique, alternative person-to-person accommodation-sharing castles, treehouses, windmills, houseboats or house-buses. International Journal of Hospitality \& Tourism Administration, 1-32.

Hidalgo, M. \& Hernandez, B. (2001). Place attachment: Conceptual and empirical questions. Journal of Environmental Psychology, 21, 273-281.

Io, M.-U. \& Wan, P.Y.K. (2018). Relationships between tourism experiences and place attachment in the context of Casino Resorts. Journal of Quality Assurance in Hospitality and Tourism, 19(1), 45-65.

Ismail, Z. \& Ali, S. (2013). Human brands: Investigating antecedents to consumers' strong attachment to celebrities. Review of Integrative Business and Economics Research, 2(2), 53-59.

Jovchelovitch, S. (2019). Knowledge in context: Representations, community and culture. Routledge, London.

Kals, E., Schumacher, D. \& Montada, L. (1999). Emotional affinity toward nature as a motivational basis to protect nature. Environment and behavior, 31(2), pp.178-202.

Kuo, D.C.L., Lin, C.C. \& Yang, J.L. (2011). Reconsidering the role of brainstorming in the marketing of technology-driven innovation. International Journal of Technology Marketing, 6(1), pp.4-16.

Kuo, T.W., Liou, B.H., Lin, K.C.J. \& Tsai, M.J. (2018). Deploying chains of virtual network functions: On the relation between link and server usage. IEEE/ACM Transactions on Networking (TON), 26(4), pp.1562-1576.

Lai, M.Y., Khoo-Lattimore, C. \& Wang, Y. (2019). Food and cuisine image in destination branding: Toward a conceptual model. Tourism and Hospitality Research, 19(2), 238-251. 
Lee, J., Kyle, G. \& Scott, D. (2012). The mediating effect of place attachment on the relationship between festival satisfaction and loyalty to the festival hosting destination. Journal of Travel Research, 51(6), pp.754-767.

Line, N.D., Hanks, L. \& Kim, W.G. (2018). An expanded servicescape framework as the driver of place attachment and word of mouth. Journal of Hospitality \& Tourism Research, 42(3), pp.476-499.

Loureiro, S.M.C. (2014). The role of the rural tourism experience economy in place attachment and behavioral intentions. International Journal of Hospitality Management, 4O, pp.1-9.

Mao, Z. \& Lyu, J. (2017). Why do travelers use Airbnb again? An integrative approach to understanding travelers' repurchase intention. International Journal of Contemporary Hospitality Management, 29(9), 2464-2482.

Maria, A.R., \& Yusniza, K. (2016). Predictors of customer Loyalty in the Malaysia hotel's outsourcing relationships.

Matura, P. \& Mapira, J. (2018). Tourism destinations, facilities, challenges and opportunities in Zimbabwe. European Journal of Social Sciences Studies.

Maziriri, E.T., Mapuranga, M. \& Madinga, N.W. (2018). Self-service banking and financial literacy as prognosticators of business performance among rural small and medium-sized enterprises in Zimbabwe. Southerm African Journal of Entrepreneurship and Small Business Management, 10(1), 1-10.

McDowell, L. (2018). Gender, identity and place: Understanding feminist geographies. John Wiley \& Sons.

McGregor, J. (2003). The Victoria Falls, 1900-1940: Landscape, tourism and the geographical imagination. Journal of Southern African Studies, 29(3), 717-737.

Miller, D.S., Gonzalez, C. \& Hutter, M. (2017). Phoenix tourism within dark tourism: Rebirth, rebuilding and rebranding of tourist destinations following disasters. Worldwide Hospitality and Tourism Themes, 9(2), 196-215.

Monecke, A. \& Leisch, F. (2012), semPLS: Structural equation modeling using partial least squares. Journal of Statistical Software, 48(3), 1-32.

Moulay, A., Ujang, N., Maulan, S. \& Ismail, S. (2018). Understanding the process of parks' attachment: Interrelation between place attachment, behavioural tendencies, and the use of public place. City, Culture and Society, 14, 28-36.

Moussa, S. \& Touzani, M. (2013). Customer-service firm attachment: What is it and what causes it? International Journal of Quality and Service Sciences, 5(3), 337-359.

Mudimba, T. \& Tichaawa, T.M. (2017). Voices of local communities regarding their involvement and roles in the tourism development process in Victoria Falls, Zimbabwe. African Journal of Hospitality, Tourism and Leisure, 6(4), $1-15$

Neuburger, L., Beck, J. \& Egger, R. (2018). The 'Phygital' tourist experience: The use of augmented and virtual reality in destination marketing. In Tourism planning and destination marketing, 183-202, Emerald Publishing, Bingley.

Nunnally, J.C. \& Bernstein, I. (1994). Psychometric theory, 3rd ed. McGraw-Hill, New York.

Papadimitriou, D., Kaplanidou, K. \& Apostolopoulou, A. (2018). Destination image components and word-ofmouth intentions in urban tourism: A multigroup approach. Journal of Hospitality \& Tourism Research, 42(4), pp.503-527.

Prayag, G. \& Ryan, C. (2012). Antecedents of tourists' loyalty to Mauritius: The role and influence of destination image, place attachment, personal involvement and satisfaction. Journal of Travel Research, 51(3), 342-356.

Prayag, G., Chen, N. \& Del Chiappa, G. (2018). Domestic tourists to Sardinia: Motivation, overall attitude, attachment, and behavioural intentions. Anatolia, 29(1), 84-97.

Price, S., Blacketer, M. \& Brownlee, M. (2018). The influence of place attachment on campers' evaluations of ecological impacts due to recreation use. Journal of Outdoor Recreation and Tourism, 21, 30-38.

Rahmani, K., Gnoth, J. \& Mather, D. (2019). A Psycholinguistic View of Tourists' Emotional Experiences. Journal of Travel Research, 58(2), pp.192-206.

Ramkissoon, H., Mavondo, F. \& Uysal, M. (2018). Social involvement and park citizenship as moderators for quality-of-life in a national park. Journal of Sustainable Tourism, 26(3), 341-361.

Ramkissoon, H., Weiler, B. \& Smith, L. (2012). Place attachment and pro-environmental behavior in national parks: The development of a conceptual framework. Journal of Sustainable Tourism, 20(2), 257-276.

Ramkissoon, H., Weiler, B. \& Smith, L.D.G. (2012). Place attachment and pro-environmental behaviour in national parks: The development of a conceptual framework. Journal of Sustainable Tourism, 2O(2), pp.257-276.

Ramsawmy, S. (2017). Gated nature and its role in creating place attachment and place identity in postapartheid South Africa: An analysis of Grotto Bay Private Residential Estate. Master's Dissertation, University of Cape Town. Cape Town.

Ramsawmy, S. (2017). Gated nature and its role in creating place attachment and place identity in postapartheid South Africa: an analysis of Grotto Bay private residential estate (Doctoral dissertation, University of Cape Town).

Ringle, C.M., Wende, S. \& Will, A. (2005). Smart PLS 2.o (Beta). University of Hamburg, Hamburg, http://www.smartpls.de. 
Schilar, H. \& Keskitalo, E.C.H. (2018). Tourism activity as an expression of place attachment-place perceptions among tourism actors in the Jukkasjärvi area of northern Sweden. Scandinavian Journal of Hospitality and Tourism, $18(\sup 1), \mathrm{S}_{42}-\mathrm{S}_{59}$.

Schild, R. (2018). Fostering environmental citizenship: The motivations and outcomes of civic recreation. Journal of Environmental Planning and Management, 61(5-6), 924-949.

Shamir, B. \& Eilam-Shamir, G. (2018). "What's your story?" A life-stories approach to authentic leadership development. In Leadership Now: Reflections on the Legacy of Boas Shamir, 51-76, Emerald Publishing, Bingley.

Shamsuddina, S. \& Ujangb, N. (2008). Making places: The role of attachment in creating the sense of place for traditional streets in Malaysia. Habitat International, 32, 399-409.

Shi, W., Cao, J., Zhang, Q., Li, Y. \& Xu, L. (2016). Edge computing: Vision and challenges. IEEE Internet of Things Journal, 3(5), pp.637-646.

Silva, C., Kastenholz, E. \& Abrantes, J.L. (2018). Linking mountain image with place-attachment. Journal of Spatial and Organizational Dynamics, 6(2), 140-152.

Slaby, J., Mühlhoff, R. \& Wüschner, P. (2019). Affective arrangements. Emotion Review, 11(1), 3-12.

Stedman, R. (2002). Toward a social psychology of place: Predicting behavior from place-based cognitions, attitude, and identity. Environment and Behaviour, 34, 561-581.

Subramaniama, C., Shamsudinb, F.M. \& Alshuaibic, A.S.I. (2017). Investigating employee perceptions of workplace safety and safety compliance using PLS-SEM among technical employees in Malaysia. Journal of Applied Structural Equation Modeling, 1(1), 44-61.

Tenenhaus, M., Amato, S. \& Esposito Vinzi, V. (2004). June. A global goodness-of-fit index for PLS structural equation modelling. In Proceedings of the XLII SIS scientific meeting (Vol. 1, pp. 739-742).

Thomson, M. (2006). Human brands: Investigating antecedents to consumers' strong attachments to celebrities. Journal of Marketing, $70(3), 104-119$.

Truong, T.L.H., Lenglet, F. \& Mothe, C. (2018). Destination distinctiveness: Concept, measurement, and impact on tourist satisfaction. Journal of Destination Marketing \& Management, 8, 214-231.

Tumanan, M.A.R. \& Lansangan, J.R.G. (2012). More than just a cuppa coffee: A multi-dimensional approach towards analyzing the factors that define place attachment. International Journal of Hospitality Management, 31(2), 529-534.

Van Loggerenberg, N. (2007). An investigation into place attachment in Newtown. MBA Thesis, University of Pretoria. Pretoria.

Wellman, B. (2018). The network community: An introduction. In Networks in the global village, 1-47, Routledge, London.

Wetzels, M., Odekerken-Schröder, G. \& Van Oppen, C. (2009). Using PLS path modeling for assessing hierarchical construct models: Guidelines and empirical illustration. MIS Quarterly, 33(1), 177-195.

Wiltshire, G., Lee, J. \& Williams, O. (2019). Understanding the reproduction of health inequalities: Physical activity, social class and Bourdieu's habitus. Sport, Education and Society, 24(3), 226-240.

Wood, E.H. \& Kenyon, A.J. (2018). Remembering together: The importance of shared emotional memory in event experiences. Event Management, 22(2), 163-181.

Woosnam, K.M., Aleshinloye, K.D., Strzelecka, M. \& Erul, E. (2018). The role of place attachment in developing emotional solidarity with residents. Journal of Hospitality \& Tourism Research, 42(7), pp.1058-1066.

Wu, H.C., Li, M.Y. \& Li, T. (2018). A study of experiential quality, experiential value, experiential satisfaction, theme park image, and revisit intention. Journal of Hospitality \& Tourism Research, 42(1), 26-73.

Wyles, K.J., White, M.P., Hattam, C., Pahl, S., King, H. \& Austen, M. (2019). Are some natural environments more psychologically beneficial than others? The importance of type and quality on connectedness to nature and psychological restoration. Environment and Behavior, 51(2), 111-143.

Xu, F., Tian, F., Buhalis, D., Weber, J. \& Zhang, H. (2016). Tourists as mobile gamers: Gamification for tourism marketing. Journal of Travel \& Tourism Marketing, 33(8), pp.1124-1142.

Yan, Q., Zhou, S. \& Wu, S. (2018). The influences of tourists' emotions on the selection of electronic word of mouth platforms. Tourism Management, 66, 348-363.

Yuksel, A., Yuksel, F. \& Bilim, Y. (2010). Destination attachment: effects on customer satisfaction and cognitive, affective and conative loyalty. Tourism Management, 31(2), pp. 274-284.

$\mathrm{http}: / / \mathrm{www}$.daiavedra.com/tour/oferte-revelion-2015-baile-felix-termal-3/, accessed 18.09.2016.

http://www.turism-36o.ro/cazare_pensiunea-selina_2568.html, accessed 02.09.2016.

http://www.vilaelim.ro/atractii/1-mai-1.html, accessed 15.09.2016.

Submitted:

20.05.2019
Revised:

07.06.2019
Accepted and published online 01.07.2019 